\title{
Aparat pomocniczy sejmiku województwa. Status prawno-instytucjonalny
}

\begin{abstract}
1. Wstęp
Zgodnie z art. 45 ust. 1 ustawy z dnia 5 czerwca 1998 r. o samorządzie województwa ${ }^{2}$ zarząd województwa wykonuje zadania województwa przy pomocy urzędu marszałkowskiego i wojewódzkich samorządowych jednostek organizacyjnych lub wojewódzkich osób prawnych. Tym samym urząd marszałkowski uczyniono aparatem pomocniczym organu wykonawczego samorządu województwa. Ustawa nie wspomina jednak w żadnym miejscu, jaka instytucja jest właściwa do obsługi sejmiku województwa. Artykuł stanowi próbę weryfikacji praktyki wypracowanej w województwach w tym zakresie, okazuje się bowiem, że niektóre rozwiązania w obszarze wsparcia funkcjonowania organów uchwałodawczych polskich regionów wywołują wątpliwości natury prawnej. Analizie poddane zostaną akty prawne i dokumenty wewnętrzne regulujące pracę aparatu pomocniczego sejmików.
\end{abstract}

\section{Podstawy prawne (czy raczej ich brak?)}

Wspomniano już wyżej, że przepisy ustawy ustrojowej nie wskazują urzędu, który miałby wspierać sejmik województwa w wykonywaniu jego zadań. Mimo to T. Lewandowski w swoim komentarzu praktycznym stwierdził, że „W polskim samorządzie urząd (starostwo) pełni funkcje subsydiarne wobec obu organów jednostki samorządu terytorialnego, tj. wobec organu wykonawczego oraz stanowiącego, choć przede wszystkim stanowi aparat pomocniczy organu wykonawczego" 3 . Podobnie wypowiedział się A. Marekwia. Uważa on, że chociaż „z przepisu art. 45 ust. 1 u.s.w. można wyciągnąć wniosek, że urząd marszałkowski jest tylko i wyłącznie aparatem pomocni-

1 Dr Igor Ksenicz, Instytut Kultury Europejskiej, Uniwersytet im. Adama Mickiewicza w Poznaniu.

2 Tekst jedn.: Dz.U. z z 2019 r. poz. 512 ze zm., dalej: u.s.w.

3 T. Lewandowski, Urzad gminy, starostwo, urzad marszałkowski jako jednostka obstugujaca organy j.s.t., LEX 2012. 
czym zarządu”, to „powszechnie przyjęło się jednak w praktyce administracji samorządowej, że urząd marszałkowski wspomaga także działalność sejmiku województwa i jego organów wewnętrznych", na co dowody spotkać można $\mathrm{w}$ doktrynie ${ }^{4}$. Na samorządową praktykę powoływał się w swoim komentarzu do ustawy również A. Szewc. Jego zdaniem wątpliwości wywoływane przez wspominany przepis powinien rozstrzygać regulamin organizacyjny urzędu odwołujący się do zapisów statutu województwa ${ }^{5}$.

Podobną linię orzeczniczą przyjęło sądownictwo administracyjne. Wojewódzki Sąd Administracyjny w Opolu w swoim wyroku z 11 września 2013 r. stwierdził, że urząd marszałkowski jest „urzędem obsługującym województwo"'. W wyroku z 8 września 2015 r. WSA w Warszawie uznał, że „urząd marszałkowski jest (...) jednostką organizacyjną województwa, zapewniającą obsługę administracyjną, organizacyjną i techniczną zarządu województwa, a w praktyce także sejmiku województwa oraz jego organów wewnętrznych"”.

Mając w pamięci stanowisko A. Szewca, należy podkreślić, że statuty tylko połowy województw - dolnośląskiego, lubuskiego, opolskiego, podkarpackiego, pomorskiego, śląskiego, świętokrzyskiego i pomorskiego wskazują urząd marszałkowski jako aparat pomocniczy sejmiku lub generalnie samorządu województwa czy organów tego samorządu. Regionalne „konstytucje” w pozostałych przypadkach powtarzają, niekiedy z drobnymi modyfikacjami, przepis art. 45 ust. 1 u.s.w.

Należy odnotować ponadto fakt uchwalenia w 2006 r. przez sejmiki trzech województw - lubelskiego, małopolskiego i śląskiego - statutów urzędu marszałkowskiego. $\mathrm{W}$ tych trzech regionach błędnie zinterpretowano przepisy art. 20 ust. 2 i art. 238 ust. 3 nieobowiązującej już ustawy $\mathrm{z}$ dnia 30 czerwca 2005 r. o finansach publicznych ${ }^{8}$, która nakładała jakoby na sejmiki obowiązek uchwalenia statutu jednostki budżetowej, jaką jest urząd marszałkowski. Niewłaściwą wykładnię przepisów wytknęly sejmikom sądy administracyjne. Wojewódzki Sąd Administracyjny w Lublinie orzekł, że „w sytuacji, kiedy organ jednostki samorządu terytorialnego nie tworzy jednostki budżetowej, to brak jest normatywnych podstaw do nadania takiej jednostce statutu, czy też do wprowadzania w nim zmian", tymczasem urzędy marszałkowskie powstały z mocy prawa, a nie decyzją organu jednostki samorządu terytorialnego. W tej samej sprawie Naczel-

4 A. Marekwia [w:] Ustawa o samorzadzie województwa. Komentarz, B. Dolnicki (red.), LEX 2012, komentarz do art. 45.

5 A. Szewc, Ustawa o samorządzie województwa. Komentarz, LEX 2008.

6 Wyrok WSA w Opolu z dnia 11 września 2013 r., I SA/Op 525/13, LEX nr 1373273.

7 Wyrok WSA w Warszawie z dnia 8 września 2015 r., V SA/Wa 1264/15, LEX nr 2030812.

8 Dz.U. Nr 249, poz. 2104 ze zm.

9 Wyrok WSA w Lublinie z dnia 23 czerwca 2009 r., III SA/Lu 244/09, CBOSA. 
ny Sąd Administracyjny stwierdził w wyroku kasacyjnym, że „uchwalenie przez Sejmik Województwa statutu urzędu marszałkowskiego, mającego obowiązywać obok statutu województwa, stanowi wkroczenie Sejmiku w obszar kompetencji przypisanych zarządowi województwa przez art. 41 ust. 2 pkt 7 ustawy o samorządzie województwa" ${ }^{10}$. Abstrahując od wadliwości prawnej uchwał, statuty urzędów lubelskiego i małopolskiego ustanowiły, a w przypadku śląskiego potwierdziły, odpowiedzialność marszałkowskiej administracji za obsługę sejmików. Paragraf 5 ust. 2 statutu Urzędu Marszałkowskiego Województwa Lubelskiego stanowi, że urząd zapewnia obsługę merytoryczną, organizacyjną, prawną, techniczną oraz kancelaryjno-biurową sejmiku, zarządu i marszałka. W analogicznym dokumencie z Małopolski zapisano, że do zadań Urzędu Marszałkowskiego Województwa Małopolskiego w Krakowie należy kompleksowa obsługa organów samorządu województwa małopolskiego, natomiast w $\$ 1$ statutu Urzędu Marszałkowskiego Województwa Śląskiego mowa jest o tym, że urząd jest jednostką organizacyjną, przy pomocy której sejmik, zarząd i marszałek realizują zadania samorządu województwa.

Szczegółowe unormowania dotyczące obsługi sejmików przez urzędy marszałkowskie, precyzujące przepisy statutów bądź wprowadzające stosowne rozwiązania instytucjonalne, powinny znaleźć się w regulaminach organizacyjnych. Znalazło to swoje odzwierciedlenie w dokumentach 14 z 16 urzędów marszałkowskich ${ }^{11}$, jednocześnie regulaminy wszystkich urzędów powołały w ich strukturze komórki organizacyjne odpowiedzialne za prawidłowe funkcjonowanie sejmików. Wzorując się na rozwiązaniach znanych z Sejmu i Senatu RP, w 13 urzędach marszałkowskich nazwano je kancelariami, a w pozostałych trzech województwach (lubuskim, opolskim i podlaskim) - biurami sejmiku. Regulaminy organizacyjne szczegółowo określają zadania tych komórek, które koncentrują się wokół obsługi prawnej czy kancelaryjno-biurowej sejmików i ich komisji, a także przewodniczących i radnych.

\section{Zwierzchnictwo nad aparatem sejmiku}

Zgodnie z art. 43 ust. 3 u.s.w. marszałek województwa jest kierownikiem urzędu marszałkowskiego oraz zwierzchnikiem służbowym pracowników tego urzędu, co oznacza, że nadzoruje on również, bezpośrednio lub pośrednio, pracę aparatu sejmiku. Tym samym marszałek jako przewodniczący organu wykonawczego samorządu województwa dysponuje bardzo

10 Wyrok NSA z dnia 16 grudnia 2009 r., II OSK 1636/09, CBOSA.

11 Regulamin Urzędu Marszałkowskiego Województwa Warmińsko-Mazurskiego w $\$ 3$ stanowi, że urząd marszałkowski jest aparatem pomocniczym do realizowania zadań zarządu województwa. Podobnie w regulaminie Urzędu Marszałkowskiego Województwa Wielkopolskiego - zgodnie z $\$ 3$ - urząd jest aparatem pomocniczym zarządu województwa i marszałka. 
silnym instrumentem wpływu na organ stanowiący. Punktem odniesienia dla tej sytuacji może być relacja pomiędzy urzędami obsługującymi Sejm RP i Radę Ministrów. Zgodnie z art. 199 ust. 1 regulaminu Sejmu ${ }^{12}$ zadania organizacyjno-techniczne i doradcze związane z jego działalnością wykonuje Kancelaria Sejmu. Kieruje nią Szef powoływany przez Marszałka Sejmu (art. 200), któremu - zgodnie z $\$ 2$ ust. 2 statutu Kancelarii Sejmu ${ }^{13}$ - również podlega. W przeciwieństwie do kancelarii czy biur sejmików, które są komórkami organizacyjnymi urzędów marszałkowskich, Kancelaria Sejmu jest - zgodnie z $\$ 1$ swojego statutu - urzędem służącym Sejmowi $i$ jego organom w zakresie prawnym, organizacyjnym, doradczym, finansowym i technicznym, kierującym się przy wykonywaniu swoich zadań zasadą bezstronności. Formalnie rząd może wpływać na działalność Kancelarii Sejmu jedynie poprzez kształtowanie jej budżetu, który jest częścią budżetu państwa. Uwzględniając jednak fakt, że Rada Ministrów ma - co do zasady - poparcie większości sejmowej, trudno wyobrazić sobie taki scenariusz.

W praktyce samorządowej zdarza się, że bezpośredni nadzór nad pracą aparatu sejmików w imieniu marszałka sprawuje sekretarz województwa. Taki mechanizm zastosowano w urzędach: kujawsko-pomorskim, lubuskim, łódzkim i śląskim. Tylko w województwie wielkopolskim decernentem kancelarii sejmiku jest inny niż marszałek członek zarządu - wicemarszałek. W pozostałych województwach kancelarie czy biura sejmiku nadzorowane są przez marszałków.

Władzę w sejmikach województw sprawują zazwyczaj koalicje partyjne. Tak długo, jak utrzymuje się regionalny sojusz polityczny, nadzór nad kancelarią sejmiku nie powinien być powodem do sporów. Sytuacja może się jednak zmienić, kiedy dojdzie do konfliktu pomiędzy dotychczasowymi koalicjantami i rozpadu większości sejmikowej. Teoretycznie marszałek może wówczas podjąć próbę obstrukcji organu uchwałodawczego, wykorzystując swoje zwierzchnictwo nad kancelarią sejmiku.

\section{Przewodniczący a aparat sejmiku}

Zgodnie z art. 20 ust. 3 u.s.w. zadaniem przewodniczącego sejmiku województwa jest wyłącznie organizowanie pracy sejmiku oraz prowadzenie jego obrad. W literaturze Uznaje się, że przewodniczący „wykonuje swe zadania za pomocą kancelarii sejmiku lub innej komórki organizacyjnej wchodzącej w skład urzędu marszałkowskiego"14. Doktryna i orzecznictwo wypowiadały się jednakowoż, że przewodniczący organów uchwałodaw-

12 Uchwała Sejmu Rzeczypospolitej Polskiej z dnia 30 lipca 1992 r. - Regulamin Sejmu Rzeczypospolitej Polskiej, tekst jedn.: M.P. z 2012 r. poz. 32 ze zm.

13 Załącznik do zarządzenia nr 6 Marszałka Sejmu z dnia 21 marca 2002 r., http:// sejm.gov.pl/Sejm8.nsf/page.xsp/KS_statut (dostęp: 4.07.2018).

14 C. Martysz [w:] Ustawa o samorządzie województwa..., komentarz do art. 20. 
czych gminy, powiatu i województwa mają zakaz nadzorowania pracy tych komórek, w tym ingerowania w pracę urzędu czy starostwa lub wydawania poleceń służbowych ich pracownikom ${ }^{15}$. Niedopuszczalne jest również tworzenie „na potrzeby obsługi działalności sejmiku kancelarii czy biura sejmiku województwa jako odrębnego zakładu pracy podporządkowanego jej przewodniczącemu"16.

Tymczasem regulaminy organizacyjne niektórych urzędów marszałkowskich przewidują współudział przewodniczącego organu uchwałodawczego w kierowaniu aparatem sejmiku:

1) $\$ 17$ ust. 1 regulaminu organizacyjnego Urzędu Marszałkowskiego Województwa Kujawsko-Pomorskiego: „Pracą Kancelarii Sejmiku kieruje dyrektor pod merytorycznym nadzorem Przewodniczącego Sejmiku”;

2) $\$ 22$ regulaminu organizacyjnego Urzędu Marszałkowskiego Województwa Lubelskiego: „Pracą pracowników Kancelarii Sejmiku kieruje Przewodniczący Sejmiku przy pomocy Dyrektora Kancelarii. Czynności z zakresu prawa pracy wobec tych pracowników dokonuje Marszałek w porozumieniu z Przewodniczącym Sejmiku";

3) $\$ 47$ regulaminu organizacyjnego Urzędu Marszałkowskiego Województwa Opolskiego: „Biuro Sejmiku w zakresie realizowanych zadań podlega Przewodniczącemu Sejmiku”;

4) $\$ 12$ ust. 3 regulaminu organizacyjnego Urzędu Marszałkowskiego Województwa Podkarpackiego: „Dyrektor Kancelarii Sejmiku wykonuje swoje zadania pod merytorycznym nadzorem Przewodniczącego Sejmiku”.

Ponadto regulamin organizacyjny urzędu w Olsztynie w $\$ 14$ ust. 4 stanowi, że strukturę organizacyjną kancelarii sejmiku zatwierdza marszałek w uzgodnieniu z przewodniczącym sejmiku. Paragraf 12 ust. 1 regulaminu urzędu w Łodzi, wymieniający komórki organizacyjne urzędu, w pkt 3 dodaje przy kancelarii sejmiku, że współpracuje ona bezpośrednio z jego przewodniczącym.

O ile unormowania z województw warmińsko-mazurskiego i łódzkiego - uzgodnienie struktury organizacyjnej kancelarii, jej współpraca z przewodniczącym - można uznać za zasadne z punktu widzenia wykonywania funkcji przewodniczącego, tak przepisy regulaminowe czterech wymienionych urzędów były do 2018 r. w sposób oczywisty niezgodne z ustawą o samorządzie województwa.

Wydawać by się mogło, że sytuację uporządkuje poselski projekt ustawy o zmianie niektórych ustaw w celu zwiększenia udziału obywateli w procesie wybierania, funkcjonowania i kontrolowania niektórych organów pu-

15 M. Augustyniak, Prawa i obowiąki radnego jednostki samorządu terytorialnego. Praktyczna wykładnia przepisów prawnych, wzory uchwat i schematy działań, LEX 2014.

16 C. Martysz [w:] Ustawa o samorządzie województwa... 
blicznych ${ }^{17}$ wniesiony do laski marszałkowskiej przez posłów koalicji rządzącej 10 listopada $2017 \mathrm{r}^{18}$ Za enigmatycznym tytułem kryła się szeroko komentowana publicznie nowelizacja Kodeksu wyborczego w części dotyczącej wyborów lokalnych oraz zmiany w ustawach samorządowych, m.in. w kwestii obsługi organów stanowiących gmin, powiatów i województw. $\mathrm{W}$ odniesieniu do tych ostatnich planowany art. 21a zakładał w ust. 1, że pracownicy urzędu marszałkowskiego wykonujący zadania organizacyjne, prawne oraz inne związane z funkcjonowaniem sejmiku województwa, komisji i radnych będą tworzyć odrębną jednostkę organizacyjną zwaną biurem sejmiku województwa, a ust. 2 przewidywał, że przewodniczący sejmiku województwa będzie wykonywać uprawnienia zwierzchnika służbowego w stosunku do pracowników biura sejmiku województwa. W uzasadnieniu do projektu wnioskodawcy nie przedstawili żadnych merytorycznych argumentów przemawiających za takim rozwiązaniem, ograniczyli się jedynie do powtórzenia przepisów.

Proponowane zmiany wywołały zdecydowaną krytykę organizacji samorządowych ${ }^{19}$. Pomijając tryb opiniowania projektu ${ }^{20}$, korporacje zwracały uwagę m.in. na:

1) niejednoznaczność przepisów - nie wiadomo było, czy biuro sejmiku miałoby stanowić odrębną od urzędu marszałkowskiego jednostkę organizacyjną czy też jedną z jego komórek;

2) brak możliwości, aby przewodniczący sejmiku - jako radny - pełnił funkcję kierownika wojewódzkiej jednostki organizacyjnej;

3) koszty związane z powołaniem nowej jednostki organizacyjnej;

17 Druk nr 2001 Sejmu VIII kadencji z 10 listopada 2017 r., http://orka.sejm.gov. pl/Druki8ka.nsf/0/07868D7E8E38658BC12581D7004FA309/\%24File/2001.pdf (dostęp: 4.07.2018).

18 Wybór inicjatywy poselskiej, a nie rządowej, zwalniał Radę Ministrów z konieczności konsultacji projektu na forum Komisji Wspólnej Rządu i Samorządu Terytorialnego.

19 Zob. do druku nr 2001: 1) opinia ZWRP, ZPP, Sejm Rzeczypospolitej Polskiej, 27 listopada 2017 r., http://orka.sejm.gov.pl/Druki8ka.nsf/0/137322B4C7517481C12581E 7004AA4A6/\%24File/2001-002.pdf (dostęp: 4.07.2018); 2) opinia ZWRP - woj. świętokrzyskie, woj. łódzkie, Sejm Rzeczypospolitej Polskiej, 30 listopada 2017 r., http://www. sejm.gov.pl/Sejm8.nsf/druk.xsp?documentId=21DFB7FF1B1F2C91C12581E80047F414 (dostęp: 4.07.2018); 3) opinia UMP, Sejm Rzeczypospolitej Polskiej, 30 listopada 2017 r., http://www.sejm.gov.pl/Sejm8.nsf/druk.xsp?documentId=7502189EF6C85595C12581 EC0037FB70 (dostęp: 4.07.2018); 4) opinia ZGWRP, Sejm Rzeczypospolitej Polskiej, 5 grudnia 2017 r., http://www.sejm.gov.pl/Sejm8.nsf/druk.xsp?documentId= 22B39E82EA8 DD5BDC12581EF003A49C6 (dostęp: 4.07.2018).

20 Związek Powiatów Polskich zwrócił uwagę w korespondencji z Kancelarią Sejmu na niedotrzymanie przez izbę wynikającego z Regulaminu Sejmu 14-dniowego terminu na wyrażenie opinii przez organizacje samorządowe. Upływał on 1 grudnia 2017 r., podczas gdy już 28 listopada 2017 r. prace nad projektem rozpoczęła podkomisja nadzwyczajna. zob. przywołaną powyżej opinię ZWRP i ZPP. 
4) brak określenia kategorii pracowników urzędu marszałkowskiego, którzy mieliby utworzyć postulowane biuro;

5) podwójną zależność służbową (wobec marszałka i przewodniczącego sejmiku) pracowników biura;

6) pominięcie w projekcie przepisów regulujących relacje pomiędzy biurem sejmiku a urzędem marszałkowskim;

7) zbyt krótki, bo 14-dniowy, termin wejścia w życie ustawy.

Komisja nadzwyczajna zajmująca się projektem częściowo przychyliła się do postulatów środowiska samorządowego. Ostatecznie Sejm przyjął 11 stycznia 2018 r. nowelizację. Do ustawy o samorządzie województwa dodano art. 21a w następującym brzmieniu: „Przewodniczący sejmiku województwa w związku z realizacją swoich obowiązków może wydawać polecenia służbowe pracownikom urzędu marszałkowskiego wykonującym zadania organizacyjne, prawne oraz inne zadania związane $\mathrm{z}$ funkcjonowaniem sejmiku województwa, komisji i radnych. W tym przypadku przewodniczący sejmiku województwa wykonuje uprawnienia zwierzchnika służbowego w stosunku do pracowników, o których mowa w zdaniu pierwszym"21. Przepisy weszły w życie 31 stycznia 2018 r. Porzucono pomysł powołania biur sejmiku jako wyodrębnionych jednostek organizacyjnych. Jednocześnie wprowadzono podwójną zależność służbową pracowników nie tylko kancelarii sejmików, ale również innych komórek organizacyjnych urzędów marszałkowskich. Organizacje samorządowe słusznie zwracały uwagę, że w prace organu stanowiącego zaangażowany jest przecież nie tylko aparat sejmiku, ale i inne departamenty, chociażby radcy prawni. Nasuwa się zatem pytanie, czy w nowym stanie prawnym marszałek jako kierownik urzędu stoi w hierarchii służbowej wyżej niż przewodniczący sejmiku? Jeśli tak, czy może zabronić wykonywania lub uchylić polecenie służbowe wydane przez przewodniczącego pracownikowi urzędu? Nowelizacja nie udziela odpowiedzi w tym zakresie.

\section{Wnioski i rekomendacje}

Dla przejrzystości funkcjonowania samorządowej administracji wojewódzkiej wskazana byłaby kolejna nowelizacja ustawy ustrojowej. W art. 45 u.s.w. można dodać przepis wskazujący na urząa marszałkowski jako aparat sejmiku, taka regulacja mogłaby znaleźć się ewentualnie także w art. 16.

Aby rozwiać przedstawione wcześniej wątpliwości, połowa polskich województw powinna zmienić swoje statuty. Należałoby wprowadzić do nich regulacje wyraźnie określające urząd marszałkowski jako aparat pomocniczy sejmiku. W dalszym ciągu do rozważenia - pod warunkiem uniknięcia

21 Ustawa z dnia 11 stycznia 2018 r. o zmianie niektórych ustaw w celu zwiększenia udziału obywateli w procesie wybierania, funkcjonowania i kontrolowania niektórych organów publicznych, Dz.U. poz. 130 ze zm. 
błędów z projektu ustawy z 2017 r. - pozostaje ustanowienie odrębnej od urzędu administracji sejmiku, której zwierzchnikiem byłby przewodniczący organu stanowiącego. Rozwiązania wprowadzone przez ostatnią nowelizację budzą jeszcze więcej wątpliwości niż dotychczas, nowe przepisy nie precyzują bowiem relacji służbowej pomiędzy marszałkiem a przewodniczącym sejmiku w zakresie nadzoru nad kancelarią sejmiku, rozciągają ponadto zwierzchnictwo przewodniczącego nad wszystkich pracowników urzędu marszałkowskiego.

\section{Bibliografia}

Augustyniak M., Prawa i obowiązki radnego jednostki samorzadu terytorialnego. Praktyczna wykładnia przepisów prawnych, wzory uchwał i schematy działań, LEX 2014.

Lewandowski T., Urzad gminy, starostwo, urzad marszałkowski jako jednostka obstugujaca organy j.s.t., LEX 2012.

Szewc A., Ustawa o samorządzie województwa. Komentarz, LEX 2008.

Ustawa o samorzadzie województwa. Komentarz, B. Dolnicki (red.), LEX 2012.

\section{Akty prawne i dokumenty}

Ustawa z dnia 5 czerwca 1998 r. o samorządzie województwa, tekst jedn.: Dz.U. z 2019 r. poz. 512 ze zm.

Ustawa z dnia 30 czerwca 2005 r. o finansach publicznych, Dz.U. Nr 249, poz. 2104, ze zm.

Ustawa z dnia 11 stycznia 2018 r. o zmianie niektórych ustaw w celu zwiększenia udziału obywateli w procesie wybierania, funkcjonowania i kontrolowania niektórych organów publicznych, Dz.U. poz. 130 ze zm.

Uchwała Sejmu Rzeczypospolitej Polskiej z dnia 30 lipca 1992 r. - Regulamin Sejmu Rzeczypospolitej Polskiej, tekst jedn.: M.P. z 2012 r. poz. 32 ze zm., poz. 32.

Poselski projekt ustawy o zmianie niektórych ustaw w celu zwiększenia udziału obywateli w procesie wybierania, funkcjonowania i kontrolowania niektórych organów publicznych, druk nr 2001 Sejmu VIII kadencji z 10 listopada 2017 r., http://orka.sejm.gov.pl/Druki8ka.nsf/0/07868D7E8E38658BC12581D7004 FA309/\%24File/2001.pdf.

Do druku nr 2001 - opinia ZWRP, ZPP, Sejm Rzeczypospolitej Polskiej, 27 listopada 2017 r., http://orka.sejm.gov.pl/Druki8ka.nsf/0/137322B4C7517481C12581E7004AA4A6/\%24File/2001-002.pdf.

Do druku nr 2001 - opinia ZWRP - woj. świętokrzyskie, woj. łódzkie, Sejm Rzeczypospolitej Polskiej, 30 listopada 2017 r., http://www.sejm.gov.pl/Sejm8.nsf/ druk.xsp?documentId=21DFB7FF1B1F2C91C12581E80047F414.

Do druku nr 2001 - opinia UMP, Sejm Rzeczypospolitej Polskiej, 30 listopada 2017 r., http://www.sejm.gov.pl/Sejm8.nsf/druk.xsp?documentId=7502189EF6 C85595C12581EC0037FB70. 
Do druku nr 2001 - opinia ZGWRP, Sejm Rzeczypospolitej Polskiej, 5 grudnia 2017 r., http://www.sejm.gov.pl/Sejm8.nsf/druk.xsp?documentId=22B39E82E A8DD5BDC12581EF003A49C6.

Statut Kancelarii Sejmu, załącznik do zarządzenia nr 6 Marszałka Sejmu z dnia 21 marca 2002 r., http://sejm.gov.pl/Sejm8.nsf/page.xsp/KS_statut.

\section{Orzecznictwo}

Wyrok NSA z dnia 16 grudnia 2009 r., II OSK 1636/09, CBOSA.

Wyrok WSA w Lublinie z dnia 23 czerwca 2009 r., III SA/Lu 244/09, CBOSA.

Wyrok WSA w Opolu z dnia 11 września 2013 r., I SA/Op 525/13, LEX nr 1373273.

Wyrok WSA w Warszawie z dnia 8 września 2015 r., V SA/Wa 1264/15, LEX nr 2030812.

\section{Statuty województw}

Uchwała nr XLIX/850/10 Sejmiku Województwa Dolnośląskiego z dnia 18 lutego 2010 r. w sprawie przyjęcia Statutu Województwa Dolnośląskiego, Dz.Urz. Woj. Dolnośląskiego Nr 47, poz. 693.

Statut Województwa Kujawsko-Pomorskiego, załącznik do obwieszczenia Sejmiku Województwa Kujawsko-Pomorskiego z dnia 17 listopada 2008 r., tekst jedn.: Dz.Urz. Woj. Kujawsko-Pomorskiego Nr 158, poz. 2465, ze zm.

Statut Województwa Lubelskiego, załącznik do obwieszczenia Sejmiku Województwa Lubelskiego z dnia 23 września 2013 r., Dz.Urz. Woj. Lubelskiego poz. 4029.

Statut Województwa Lubuskiego, załącznik do uchwały nr XL/462/13 Sejmiku Województwa Lubuskiego z dnia 9 września 2013 r., Dz.Urz. Woj. Lubuskiego poz. 1992.

Statut Województwa Łódzkiego, załącznik do uchwały nr XXX/775/08 Sejmiku Województwa Łódzkiego z dnia 26 sierpnia 2008 r., Dz.Urz. Woj. Łódzkiego Nr 316, poz. 2704.

Statut Województwa Małopolskiego, załącznik do obwieszczenia Sejmiku Województwa Małopolskiego z dnia 31 sierpnia 2015 r. w sprawie ogłoszenia jednolitego tekstu Statutu Województwa Małopolskiego, Dz.Urz. Woj. Małopolskiego poz. 5483.

Statut Województwa Mazowieckiego, załącznik do uchwały nr 145/09 Sejmiku Województwa Mazowieckiego z dnia 7 września 2009 r., Dz.Urz. Woj. Mazowieckiego Nr 144, poz. 4385.

Uchwała nr XXXVII/346/2005 Sejmiku Województwa Opolskiego z dnia 26 lipca 2005 r. w sprawie uchwalenia Statutu Województwa Opolskiego, załącznik do obwieszczenia Sejmiku Województwa Opolskiego z dnia 30 września 2014 r., tekst jedn.: Dz.Urz. Woj. Opolskiego poz. 2201.

Statut Województwa Podkarpackiego, załącznik do uchwały nr X/103/99 Sejmiku Województwa Podkarpackiego w Rzeszowie z dnia 29 września 1999 r., Dz.Urz. Woj. Podkarpackiego Nr 28, poz. 1247 ze zm.

Statut Województwa Podlaskiego, załącznik do uchwały nr XIV/131/04 Sejmiku Województwa Podlaskiego z dnia 26 stycznia 2004 r., Dz.Urz. Woj. Podlaskiego $\mathrm{Nr} 13$, poz. 270 ze zm. 
Statut Województwa Pomorskiego, załącznik do uchwały nr 270/XXI/2000 z dnia 3 lipca 2000 r. Sejmiku Województwa Pomorskiego, tekst jedn.: Dz.Urz. Woj. Pomorskiego z 2002 r. Nr 39, poz. 905 ze zm.

Uchwała nr I/33/2/01 Sejmiku Województwa Śląskiego z dnia 23 kwietnia 2001 r. w sprawie uchwalenia Statutu Województwa Śląskiego, Dz.Urz. Woj. Śląskiego Nr 26, poz. 657 ze zm.

Statut Województwa Świętokrzyskiego, załącznik do obwieszczenia przewodniczącego Sejmiku Województwa Świętokrzyskiego z dnia 30 grudnia 2009 r., tekst jedn.: Dz.Urz. Woj. Świętokrzyskiego z 2010 r. Nr 70, poz. 520.

Statut Województwa Warmińsko-Mazurskiego, załącznik do obwieszczenia nr XXII/512/16 Sejmiku Województwa Warmińsko-Mazurskiego z dnia 29 listopada 2016 r., Dz.Urz. Woj. Warmińsko-Mazurskiego poz. 4971.

Statut Województwa Wielkopolskiego, załącznik nr 1 do obwieszczenia Sejmiku Województwa Wielkopolskiego z dnia 17 grudnia 2012 r., tekst jedn.: Dz.Urz. Woj. Wielkopolskiego z 2013 r. poz. 431.

Statut Województwa Zachodniopomorskiego, załącznik nr 1 do obwieszczenia Sejmiku Województwa Zachodniopomorskiego z dnia 15 marca 2004 r., tekst jedn.: Dz.Urz. Woj. Zachodniopomorskiego Nr 24, poz. 456 ze zm.

\section{Statuty urzędów marszałkowskich}

Statut Urzędu Marszałkowskiego Województwa Lubelskiego w Lublinie, załącznik do uchwały nr XLVIII/755/06 Sejmiku Województwa Lubelskiego z dnia 10 lipca $2006 \mathrm{r}$.

Statut Urzędu Marszałkowskiego Województwa Małopolskiego, załącznik do uchwały nr XLVI/601/06 Sejmiku Województwa Małopolskiego z dnia 3 lipca 2006 r., Dz. Urz. Woj. Małopolskiego Nr 484, poz. 2961.

Statut Urzędu Marszałkowskiego Województwa Śląskiego, załącznik do uchwały Sejmiku Województwa Śląskiego nr II/49/19/2006 z dnia 12 czerwca 2006 r.

\section{Regulaminy organizacyjne urzędów marszałkowskich}

Regulamin organizacyjny Urzędu Marszałkowskiego Województwa Dolnośląskiego, załącznik do uchwały nr 92/V/15 Zarządu Województwa Dolnośląskiego $\mathrm{z}$ dnia 2 lutego 2015 r. ze zm.

Regulamin organizacyjny Urzędu Marszałkowskiego Województwa KujawskoPomorskiego w Toruniu, załącznik do uchwały 24/763/15 Zarządu Województwa Kujawsko-Pomorskiego z dnia 17 czerwca 2015 r. ze zm.

Regulamin organizacyjny Urzędu Marszałkowskiego Województwa Lubelskiego w Lublinie, tekst jedn.: załącznik do uchwały nr CCVII/4115/2017 Zarządu Województwa Lubelskiego z dnia 22 sierpnia 2017 r.

Regulamin organizacyjny Urzędu Marszałkowskiego Województwa Lubuskiego w Zielonej Górze, załącznik do uchwały nr 161/2142/17 Zarządu Województwa Lubuskiego z dnia 10 stycznia 2017 r. ze zm.

Regulamin organizacyjny Urzędu Marszałkowskiego Województwa Łódzkiego, załącznik do uchwały nr 240/17 Zarządu Województwa Łódzkiego z dnia 1 marca $2017 \mathrm{r}$. 
Regulamin organizacyjny Urzędu Marszałkowskiego Województwa Małopolskiego, załącznik do uchwały nr 444/16 Zarządu Województwa Małopolskiego $\mathrm{z}$ dnia 24 marca $2016 \mathrm{r}$.

Regulamin organizacyjny Urzędu Marszałkowskiego Województwa Mazowieckiego w Warszawie, tekst jedn.: załącznik do uchwały nr 1680/105/15 Zarządu Województwa Mazowieckiego z dnia 15 grudnia 2015 r. ze zm.

Regulamin organizacyjny Urzędu Marszałkowskiego Województwa Opolskiego, załącznik do uchwały Zarządu Województwa Opolskiego nr 2601/2016 z dnia 13 września $2016 \mathrm{r}$.

Regulamin organizacyjny Urzędu Marszałkowskiego Województwa Podkarpackiego w Rzeszowie, załącznik do uchwały nr 262/6420/13 Zarządu Województwa Podkarpackiego w Rzeszowie z dnia 27 sierpnia 2013 r. ze zm.

Regulamin organizacyjny Urzędu Marszałkowskiego Województwa Podlaskiego w Białymstoku, załącznik do uchwały nr 181/2362/2016 Zarządu Województwa Podlaskiego z dnia 19 grudnia 2016 r.

Uchwała nr 148/209/17 Zarządu Województwa Pomorskiego z dnia 7 lutego 2017 r. w sprawie uchwalenia Regulaminu Organizacyjnego Urzędu Marszałkowskiego Województwa Pomorskiego.

Regulamin organizacyjny Urzędu Marszałkowskiego Województwa Śląskiego przyjęty uchwałą nr 1813/214/V/2017 Zarządu Województwa Śląskiego z dnia 29 sierpnia $2017 \mathrm{r}$.

Regulamin organizacyjny Urzędu Marszałkowskiego Województwa Świętokrzyskiego w Kielcach, załącznik do uchwały nr 841/11 Zarządu Województwa Świętokrzyskiego z dnia 30 grudnia $2011 \mathrm{r}$.

Regulamin organizacyjny Urzędu Marszałkowskiego Województwa Warmińsko-Mazurskiego w Olsztynie, załącznik do uchwały nr 14/161/17/V Zarządu Województwa Warmińsko-Mazurskiego z dnia 28 lutego 2017 r.

Regulamin organizacyjny Urzędu Marszałkowskiego Województwa Wielkopolskiego w Poznaniu, załącznik do uchwały nr 828/2015 Zarządu Województwa Wielkopolskiego z dnia 16 lipca 2015 r. ze zm.

Regulamin organizacyjny Urzędu Marszałkowskiego Województwa Zachodniopomorskiego w Szczecinie przyjęty uchwałą nr 1935/15 Zarządu Województwa Zachodniopomorskiego z dnia 9 grudnia 2015 r., tekst jedn. ze zm.

Streszczenie

Artykuł przedstawia wątpliwości prawne związane z funkcjonowaniem aparatu pomocniczego sejmików województw - kancelarii i biur sejmików, okazuje się bowiem, że praktyki polskich regionów w tym zakresie nie zawsze są zgodne $\mathrm{z}$ ustawą o samorządzie województwa. Co więcej, niejasne regulacje dotyczące zwierzchnictwa nad kancelariami sejmików mogą skutkować zachwianiem równowagi między organami uchwałodawczymi a wykonawczymi samorządów województw. Podstawę analizy prawno-instytucjonalnej stanowią: ustawodawstwo, orzecznictwo oraz literatura przedmiotu, a przede wszystkim akty prawa miejscowego i kierownictwa wewnętrznego - statuty województw oraz regulaminy organizacyjne urzędów marszałkowskich. Autor przedstawia w zakończeniu postulaty de lege ferenda.

Słowa kluczowe: sejmik województwa, kancelaria sejmiku, przewodniczący sejmiku, marszałek województwa 


\section{Subsidiary Bodies of Regional Assemblies in Poland: Their Legal and Institutional Status}

Abstract

The article presents legal questions related to the work of subsidiary bodies of Polish regional assemblies, i.e. their chancelleries or offices. It seems that practices of Polish regional authorities in this regard are not always in line with the the Regional Government Act. Moreover, unclear regulations concerning the supervision of chancelleries may cause an imbalance between legislative and executive bodies of regional government. The legal and institutional analysis is based on legal acts, jurisdiction, literature on the subject and, most importantly, local and internal administration acts: statutes of regions and organisational regulations of regional administrations (offices of the marshal). In conclusion, the author presents some legislative recommendations.

Keywords: regional assembly, chancellery of the regional assembly, president of the regional assembly, marshal of the region 